\title{
IDENTIFIKASI JENIS KELAMIN SIPUT GONGGONG Strombus sp. SECARA MORFOLOGI DI PERAIRAN MADUNG, TANJUNGPINANG, INDONESIA
}

\section{SEX IDENTIFICATION THE DOG CONCH Strombus Sp. ONLY MORPHOLOGY IN MADUNG WATERS, TANJUNGPINANG, INDONESIA}

\author{
Susiana $^{1}$, Azwin Apriandi ${ }^{2}$ dan Rochmady ${ }^{3 *}$ \\ ${ }^{1}$ Jurusan Manajemen Sumberdaya Perairan, FIKP, UMRAH, Tanjungpinang, 29115 \\ ${ }^{2}$ Jurusan Teknologi Hasil Perikanan, FIKP, UMRAH, Tanjungpinang, 29115 \\ ${ }^{3}$ Pusat Studi Pesisir dan Pulau-Pulau Kecil, STIP Wuna, Raha, 93654 \\ *E-mail: rochmady@stipwunaraha.ac.id
}

\begin{abstract}
Morphological identification as an alternative sex identification of dog conch without damaging the shell and viscera. The study aimed to identify the gender of the dog conch Strombus sp. by morphology. Samples were obtained from fishermen collecting dog conch on the coast of Madung, Tanjungpinang, Indonesia. Samples were collected by hand at low tide. To distinguish between male and female dog conch is done by looking at the shell structure morphologically without seeing the internal organs of the body shell. To see the gonads or reproductive organs is done by removing the whole dog conch by breaking the shell. The shell length was measured using by caliper a precision $0.01 \mathrm{~mm}$. The length of the shell is the distance from the anterior edge to the posterior end of the shell. To know the sex ratio of dog conch type analyzed chi-square. The data obtained were analyzed descriptively. The results showed that of the total sample of 1124 individuals, obtained two types of dog conch are Strombus canarium and Strombus sp. The determination of the gender of morphological dog conch can be seen from the structure of the shell (width and slim). The wide shell shape signifies a female, a slim form of shell signifying a male. The sex ratio of dog conch type $S$. canarium and Strombus sp. males and females in different ratios.
\end{abstract}

Keywords: dog conch, gender, Madung waters, morphology, sex ratio

\begin{abstract}
ABSTRAK
Identifikasi morfologi sebagai alternatif identifikasi jenis kelamin siput gonggong tanpa merusak cangkang dan viscera. Penelitian bertujuan untuk mengidentifikasi jenis kelamin siput gonggong Strombus sp. secara morfologi. Sampel diperoleh dari nelayan pengumpul di pesisir Madung, Tanjungpinang, Indonesia. Sampel dikoleksi pada saat surut terendah, hasil koleksi disimpan dalam wadah ember. Siput gonggong jenis kelamin jantan dan betina dibedakan secara morfologi melalui pengamatan visual terhadap cangkang tanpa pembedaan organ bagian dalam cangkang. Organ reproduksi diketahui dengan cara mengeluarkan keseluruhan daging dengan memecahkan cangkang. Panjang cangkang diukur menggunakan kaliper dengan ketelitian 0,01 mm. Panjang cangkang adalah jarak dari ujung anterior ke ujung posterior cangkang. Rasio jenis kelamin siput gonggong dianalisis dengan metode chi-square. Data yang diperoleh dianalisis secara deskriptif. Hasil penelitian menunjukkan bahwa siput gonggong yang ditemukan adalah jenis Strombus canarium dan Strombus sp. dari total sampel sebanyak 1124 individu. Jenis kelamin siput gonggong dapat ditentukan secara morfologi berdasarkan kemontokan cangkang (lebar dan langsing). Bentuk cangkang lebar menandakan siput gonggong jenis kelamin betina, bentuk cangkang langsing menandakan siput gonggong jenis kelamin jantan. Nisbah kelamin siput gonggong jenis S. canarium dan Strombus sp. jantan dan betina dalam rasio berbeda.
\end{abstract}

Kata kunci: gonggong, jenis kelamin, morfologi, nisbah kelamin, perairan Madung 


\section{PENDAHULUAN}

Siput gonggong atau gonggong Strombus sp. atau lebih dikenal sebagai $d o g$ conch merupakan gastropoda laut dari famili Strombidae (Carpenter and Niem, 1998). Siput gonggong memiliki beragam manfaat, baik secara ekonomi maupun secara ekologi. Secara ekonomi diantaranya dagingnya dimanfaatkan sebagai bahan makan (Muzahar and Hakim, 2018), cangkangnya sebagai hiasan (Venkatesan, 2010). Secara ekologi cangkangnya berpotensi sebagai bahan absorbsi logam berat $(\mathrm{Pb} 2+)$ (Hadi, 2016), selain itu sebagai indikator kesuburan perairan padang lamun (Adulyanukosol and Poovachiranon, 2006; Cob et al., 2010, 2012), oleh karena kehadiran siput gonggong terkait dengan keberadaan padang lamun (Chim et al., 2009; Cob et al., 2014). Dibeberapa negara gonggong dimanfaatkan sebagai indikator bagi kesuburan maupun pencemaran perairan (Arifin, 2011). Terlepas dari itu, sejak tahun 50-an siput gonggong telah diperdagangkan sebagai bahan makanan dan hiasan dengan nilai ekonomi cukup tinggi (Davis et al., 1987).

Siput gonggong merupakan salah satu jenis Gastropoda yang banyak ditemukan di perairan tropis (Dody, 2011; Cob et al., 2014), salah satunya wilayah Kepulauan Riau (Setyono, 2006). Penelitian awal siput gonggong di perairan Indonesia dimulai sejak tahun 1980-an oleh Amini (1986) yang mengungkap informasi awal tentang gonggong di Pulau Bintan, Kepulauan Riau. Dalam perkembangannya, siput gonggong sangat diminati oleh masyarakat setempat maupun pendatang yang dijadikan sebagai bahan makanan untuk dikonsumsi, bahkan kini menjadi ikon Propinsi Kepulauan Riau (Muzahar and Hakim, 2018). Gonggong dimanfaatkan sebagai makanan khas baik sebagai lauk (gonggong rebus) maupun hasil olahan seperti kerupuk, bakwan, dan lainnya (Waris et al., 2014; Muzahar and Hakim, 2018). Hal ini ditengarai sebagai salah satu sebab permintaan pasar akan siput gonggong terus meningkat dari waktu ke waktu (Siddik, 2011). Permintaan pasar yang relatif tinggi tersebut dikhawatirkan dapat terjadi over exploitasi. Apalagi siput gonggong sebagai biota sesil memiliki pergerakan lambat, sehingga relatif mudah dieksploitasi masyarakat pesisir (Dody, 2011). Nelayan pengumpul atau pengambil gonggong ditengarai belum memperhatikan keberlanjutan populasi siput gonggong di alam, oleh karena yang diambil rata-rata ukuran $53,879 \pm 2,084 \mathrm{~mm}$ sebagai ukuran matang gonad (Waris et al., 2014). Akibatnya semakin sulit menemukan siput gonggong yang berukuran besar. Siput gonggong yang banyak ditemukan di pasar maupun rumah makan atau restoran hanya yang berukuran kecil atau dalam kisaran ukuran matang gonad.

Jumlah pengambilan siput gonggong di Pulau Bintan, Kepulauan Riau mencapai 500-600 individu per hari per nelayan, dan pada saat musim puncak (Mei-Oktober) bisa mencapai 3.000-4.000 individu per hari per nelayan (Viruly, 2011). Tingginya permintaan siput gonggong dipasaran diduga kuat menjadi penyebab masifnya pengambilan gonggong di alam. Berdasarkan penelitian Waris et al. (2014) bahwa siput gonggong di perairan Madong, Tanjungpinang, Kepulauan Riau memiliki ukuran minimum sebesar $41,44 \mathrm{~mm}$, dan ukuran maksimum sebesar 84,71 mm. Di perairan Johor, Malaysia dilaporkan bahwa ukuran panjang cangkang siput gonggong mencapai 69,30 mm untuk jantan dan 70,20 mm untuk betina (Cob et al., 2009c). Hal yang sama ditemukan pada siput gonggong di perairan Teluk Klabat, Bangka-Belitung, ukuran panjang cangkang terkecil sebesar $20,39 \mathrm{~mm}$, ukuran panjang cangkang terbesar sebesar 79,68 mm (Siddik, 2011). Walau bagaimanapun ukuran panjang cangkang siput gonggong di perairan Madung, Tanjungpinang lebih besar dibanding di daerah lain, namun dengan masifnya aktifitas pengambilan, di-khawatirkan dapat terjadi penurunan ukuran cangkang dan jumlah 
populasi oleh karena belum adanya tindakan pengelolaan seperti penetapan daerah kawasan konservasi gonggong, daerah perlindungan, atau semacamnya.

Sebagaimana dilaporkan Reed (1991), penelitian siput gonggong di beberapa negara telah mengarah ke budidaya, pengembangan teknologi pembenihan (Robertson, 1959), maupun pengujian pembenihan dalam skala laboratorium (Cob et al., 2009b). Di Indonesia, berbagai penelitian telah berkembang dan relatif cukup maju, seperti pemanfaatan gonggong sebagai bioindikator pencemaran perairan (Arifin, 2011), maupun pengembangan ke arah budidaya melalui kegiatan pembenihan dalam skala laboratorium (Dody, 2012; Muzahar and Hakim, 2018). Diketahui, siput gonggong memiliki kelamin terpisah (dioceus) (Dody, 2012), yakni jenis kelamin jantan dan betina terdapat pada individu berbeda. Pendekatan identifikasi jenis kelamin masih berdasar pada struktur anatomi viscera (Cob et al., 2008), yakni hasil pengamatan secara anatomis akan terlihat gonad atau organ reproduksinya. Walaupun demikian, identifikasi jenis kelamin secara mikroskopik telah dilakukan (Delgado et al., 2004; Tiley et al., 2019). Namun demikian, untuk kepentingan konservasi saat ini penentuan jenis kelamin siput gonggong masih mengandalkan pengetahuan secara anatomi yakni dengan mengeluarkan daging dari cangkangnya, baik dengan cara memecahkan cangkangnya atau dengan cara direbus terlebih dahulu. Pendekatan ini cukup akurat namun memiliki kelemahan, oleh karena gonggong tidak bisa lagi dilepaskan di alam karena cangkang dan dagingnya dirusak. Untuk itu perlu dilakukan penelitian untuk mengetahui jenis kelamin gonggong secara morfologi sebagai alternatif dalam identifikasi jenis kelamin tanpa harus merusak cangkang dan daging siput.

Namun bagaimanapun, minimnya bahkan relatif belum adanya data dan informasi tentang jenis kelamin yang bisa diketahui langsung berdasarkan morfologi cangkang meliputi warna, bukaan cangkang (aperture), dan panjang cangkang gonggong sangat disayangkan bila terjadi kepunahan spesies sebelum informasi dasar tersebut terungkap. Penelitian ini diharapkan dapat memberikan nilai tambah terhadap informasi tentang gastropoda di Indonesia serta dapat dijadikan sebagai informasi dasar dalam pengelolaan gonggong. Selain itu, penelitian ini diharapkan memberi informasi awal bagi kajian bioekologi gonggong.

\section{METODE PENELITIAN}

\subsection{Waktu dan Tempat}

Penelitian ini dilaksanakan pada bulan Mei-Oktober 2017, dengan pengambilan contoh dilakukan sebanyak 12 kali dengan interval waktu satu kali dalam dua pekan. Pengambilan sampel dilaksanakan di daerah pesisir perairan Madung, Kota Tanjung-pinang, Kepulauan Riau, Indonesia (Gambar 1). Gonggong yang diperoleh dari nelayan kemudian dikumpulkan dan dianalisis untuk membedakan jenis kelamin bertempat di Laboratorium Fakultas Ilmu Kelautan dan Perikanan Universitas Maritim Raja Ali Haji.

\subsection{Alat dan Bahan}

Peralatan yang digunakan adalah perahu untuk menuju lokasi penelitian. Selanjutnya dalam parameter biologi digunakan ember untuk menyimpan contoh siput gonggong, kaliper ketelitian $0,01 \mathrm{~mm}$ untuk mengukur panjang cangkang siput gonggong. Dokumentasi penelitian menggunakan kamera serta alat tulis menulis. Bahan yang digunakan adalah siput gonggong Strombus sp. yang diperoleh dari nelayan di lokasi penelitian.

\subsection{Prosedur dan Teknik Pengumpulan Data}

Pencuplikan (sampling) siput gonggong dilakukan dengan prinsip keterwakilan, yakni dengan membeli siput gonggong dari nelayan yang menangkap 


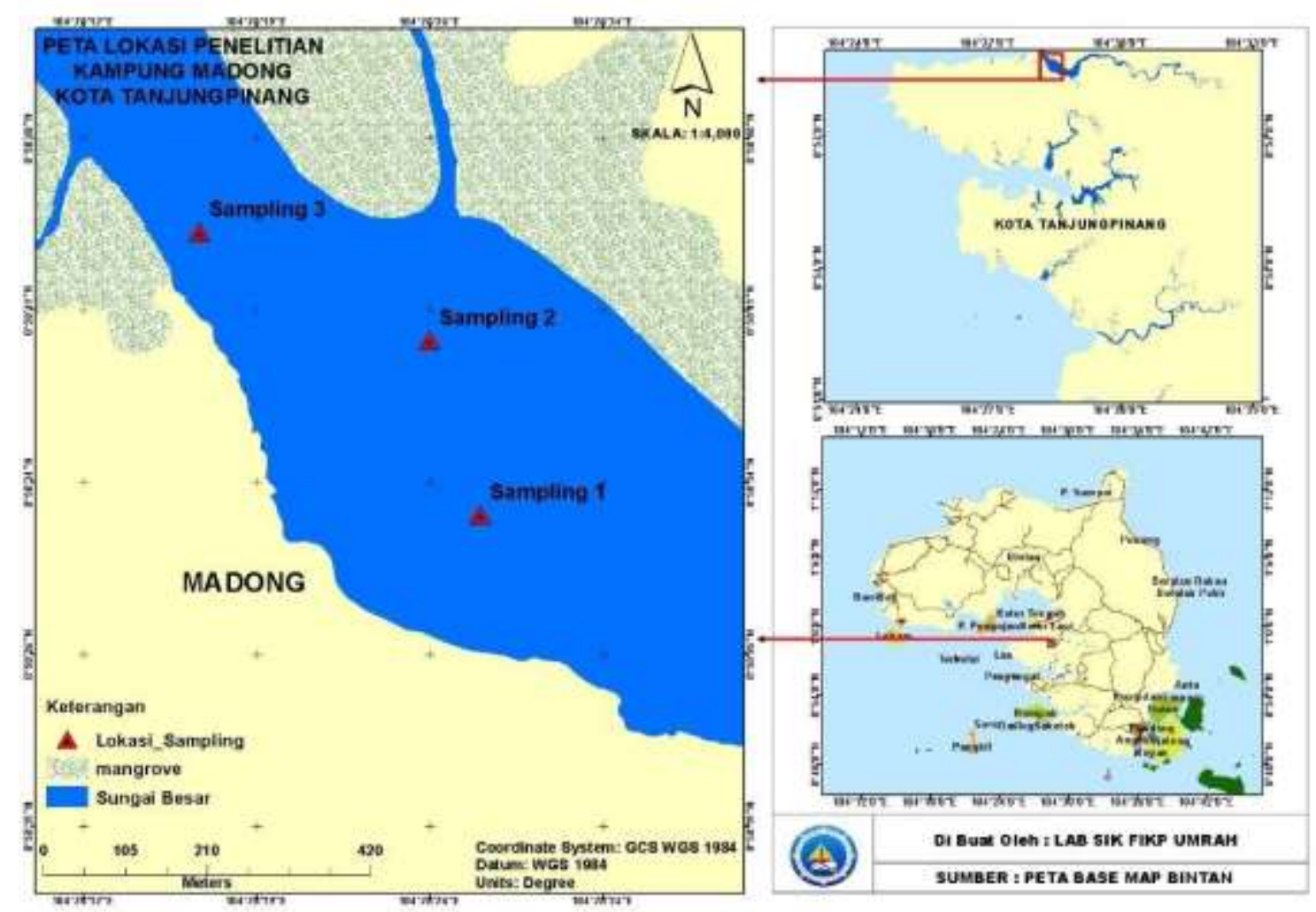

Gambar 1. Lokasi pengambilan sampel siput gonggong Strombus sp. di Perairan Madung, Tanjungpinang, Indonesia.

sampel di lokasi perairan Madung, Tanjung pinang, Kepulauan Riau, Indonesia. Koleksi sampel dilakukan pada saat surut terendah dengan cara memungut langsung siput gonggong. Selanjutnya hasil koleksi siput gonggong disimpan dalam wadah ember dan dikumpulkan dalam keranjang pengumpul. Individu siput gonggong yang diperoleh kemudian dihitung jumlah keseluruhannya sebelum diidentifikasi.

Siput gonggong jenis kelamin jantan dan betina dibedakan dengan cara pengamatan visual cangkang meliputi warna, bukaan cangkang (aperture), dan pengukuran panjang cangkang. Panjang cangkang siput gonggong diukur menggunakan kaliper ketelitian 0,01 mm. Panjang cangkang yang diukur adalah jarak dari ujung anterior ke ujung posterior cangkang. Selain itu juga dihitung nisbah atau rasio kelamin jantan dan betina yang terdapat di alam.

\subsection{Analisis Data}

\subsubsection{Identifikasi Jenis Kelamin}

Data identifikasi secara morfologi ditabulasikan dan dibuat dalam bentuk diagram, kemudian diinterpretasi sesuai dengan hasil pengamatan. Hasil pengamatan kemudian dianalisis secara deskriptif.

\subsubsection{Nisbah Kelamin}

Data hasil identifikasi yang sudah terkumpul pada setiap waktu pengamatan dipisahkan menurut jenis kelamin dan stasiun pengamatan kemudian dianalisis dengan hipotesis pengambilan keputusan sebagai berikut:

$\mathrm{H}_{0}$ : tidak ada perbedaan antara jumlah siput gonggong jantan dan betina yang muncul (nisbah kelamin antara jantan 289 dan betina adalah seimbang, yakni $1: 1)$.

$\mathrm{H}_{1}$ : terdapat perbedaan antara jumlah siput gonggong jantan dan betina yang muncul. 
Nisbah kelamin dihitung dengan cara membandingkan jumlah siput gonggong jantan dan betina. Nisbah kelamin dianalisis menggunakan uji chi-square $\left(\mathrm{X}^{2}\right)$ dalam bentuk tabel kontigensi (Sugiyono, 2006) dengan formula sebagai berikut:

$\mathrm{X}^{2}=\sum_{\mathrm{i}=1_{2}, 3}^{\mathrm{s} 3} \frac{(f i-\mathrm{F})^{2}}{\mathrm{~F}}$

Keterangan:

$\mathrm{X}^{2}=$ nilai distribusi kelamin, $f i=$ nilai pengamatan ke-i, $F=$ nilai harapan ke-i, i adalah 1,2,3, dan $\mathrm{S}=$ jumlah pengamatan.

Taraf kepercayaan 0,05 dengan nilai $\mathrm{X}^{2}$ tabel db (B-1) dan (K-1) dimana B merupakan kategori baris dan $\mathrm{K}$ merupakan kategori kolom, dengan kriteria pengujian sebagai berikut:

$\mathrm{H}_{0}$ : diterima, $\mathrm{H}_{1}$ : ditolak, apabila $\mathrm{X}^{2}$ hitung $\leq$ $X^{2}$ tabel $(\alpha=0,05)$;

$\mathrm{H}_{0}$ : ditolak, $\mathrm{H}_{1}$ : diterima, apabila $\mathrm{X}^{2}$ hitung $>$ $\mathrm{X}^{2}$ tabel $(\alpha=0,05)$.

\section{HASIL DAN PEMBAHASAN}

\subsection{Identifikasi Jenis Kelamin}

Total sampel siput gonggong yang diperoleh selama penelitian sebanyak 1124 individu. Identifikasi jenis kelamin secara morfologi dilihat dari kajian struktur cangkang, warna, bukaan cangkang (aperture) dan panjang cangkang. Bentuk cangkang siput gonggong ditemukan memiliki postur/bentuk berbeda, yakni postur cangkang lebar dan langsing dari kedua spesies yang ditemukan. Cangkang dengan bentuk lebar secara morfologi menandakan siput gonggong dengan jenis kelamin betina (Gambar 2A dan 2B). Sedangkan cangkang dengan bentuk lebih langsing menandakan siput gonggong jenis kelamin jantan (Gambar 2C). Hal ini telah dibuktikan dengan mengeluarkan daging gonggong untuk melihat jenis kelamin secara morfologi (Gambar 4).

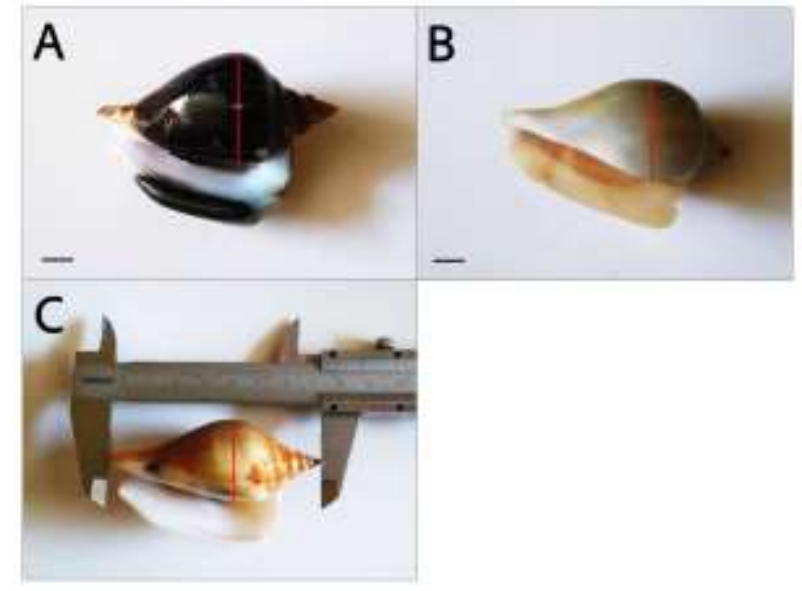

Gambar 2. Bentuk cangkang lebar siput gonggong jenis kelamin bentina (A dan B), bentuk cangkang langsing jenis kelamin jantan (C). Keterangan: - merupakan tanda identifikasi morfologi cangkang.

Warna cangkang pada siput gonggong bervariasi dari kehitaman, kecoklatan, kuning keemasan, krem, dan putih (Gambar 2). Dari warna cangkang sulit membedakan jenis kelamin siput gonggong. Bukaan cangkang (aperture) siput gonggong ada yang dangkal dan ada yang melebar (Gambar 2A dan 2B). Bukaan cangkang yang melebar biasanya siput gonggong tersebut telah memasuki masa pemijahan. Hal ini sebagaimana yang dikemukan oleh Davis (2005) dan Dody (2012), bahwa siput gonggong jenis strombus (Strombus gigas) dewasa memiliki kelamin terpisah dan akan mengalami kematangan seksual setelah tepi luar cangkangnya (lip) berkembang secara penuh. Dengan demikian pendekatan warna cangkang dan bukaan cangkang sulit dijadikan sebagai indikator perbedaan jenis kelamin jantan dan betina.

Panjang cangkang siput gonggong bervariasi berdasarkan jenis kelamin dari dua spesies yang ditemukan. Dua spesies yang ditemukan adalah $S$. canarium dan Strombus sp. Perbandingan panjang cangkang siput gonggong disajikan pada Tabel 1 . 
Tabel 1. Panjang cangkang siput gonggong yang dikoleksi di perairan Madung, Tanjungpinang, Indonesia.

\begin{tabular}{lcc}
\hline \multicolumn{1}{c}{ Jenis } & \multicolumn{2}{c}{ Panjang Cangkang $(\mathrm{cm})$} \\
Kelamin & S. canarium & Strombus sp. \\
\hline Jantan & $2,52-8,44$ & $5,41-7,37$ \\
Betina & $5,07-8,80$ & $5,60-8,13$ \\
\hline
\end{tabular}

Berdasarkan Tabel 1, panjang cangkang siput gonggong jenis $S$. canarium yang dikumpulkan nelayan mulai dari ukuran kecil sebesar 2,52 $\mathrm{cm}$ atau 25,2 mm untuk siput gonggong jenis kelamin jantan, dan sebesar 5,07 cm untuk jenis kelamin betina. Dengan demikian, sampel dianalisis secara morfologi dengan cara identifikasi tanda khusus berupa tonjolan dan dikonfirmasi secara anatomi. Hasil identifikasi secara anatomi (Gambar 3) menunjukkan terdapat perbedaan ber-dasarkan jumlah koleksi sampel menurut perbandingan jenis kelamin jantan dan betina pada masing-masing spesies.

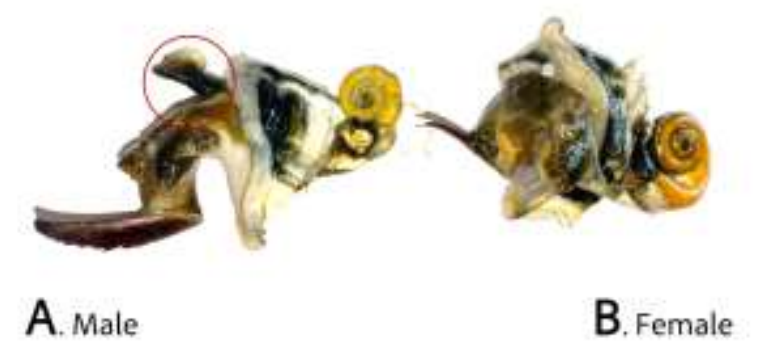

Gambar 3. Organ reproduksi siput gonggong jantan berupa tonjolan (A), sementara pada jenis kelamin betina tidak memiliki tonjolan (B). Keterangan: tanda $\mathrm{O}$ menunjukkan organ reproduksi jenis kelamin jantan.

Identifikasi secara anatomi sebagai indikator kuat yang telah lama digunakan untuk membedakan jenis kelamin jantan dan betina pada siput gonggong adalah adanya sembulan (tonjolan) khusus pada daging (viscera) (Brito-Manzano and Aranda, 2004;
Cob et al., 2009a, 2011; Enriquez-Diaz et al., 2014). Hal ini diperkuat dengan hasil pemeriksaan mikroskopik (histologi) (Delgado et al., 2004; Tiley et al., 2019). Adanya penanda berupa tonjolan dijadikan pembeda untuk jenis kelamin jantan dan betina pada siput gonggong, sehingga hal tersebut menjadi umum digunakan.

Perbandingan jenis kelamin jantan dan betina sebagaimana dimaksud disajikan pada Tabel 2. Siput gonggong jenis $S$. canarium cenderung lebih banyak dari jenis Strombus sp. baik secara keseluruhan maupun berdasarkan jenis kelamin.

Tabel 2. Perbandingan jumlah siput gonggong berdasarkan jenis kelamin yang dikoleksi di perairan Madung, Tanjungpinang, Indonesia.

\begin{tabular}{lccc}
\hline $\begin{array}{c}\text { Jenis } \\
\text { Kelamin }\end{array}$ & $\begin{array}{c}\text { S. } \\
\text { canarium }\end{array}$ & $\begin{array}{c}\text { Strombus } \\
\text { sp }\end{array}$ & Total \\
\hline Jantan & 421 & 224 & 645 \\
Betina & 253 & 226 & 479 \\
Total & 674 & 445 & 1124 \\
\hline
\end{tabular}

Pengamatan bentuk cangkang dikombinasi dengan pengamatan anatomi terhadap penanda jenis kelamin untuk hasil yang diperoleh lebih akurat. Secara anatomi, jenis kelamin siput gonggong dapat dibedakan dari organ reproduksi yakni adanya tonjolan untuk jenis kelamin jantan (Dody, 2012). Perbedaan secara mencolok antara jenis kelamin jantan dan betina secara anatomi dapat diihat pada Gambar 3. Pada (Gambar 3A) bertanda lingkaran (O) memperlihatkan dengan jelas adanya tanda khusus pada jenis kelamin jantan. Siput gonggong pada jenis kelamin betina (Gambar 3) tidak menunjukkan adanya tanda khusus tersebut (tonjolan) (Reed, 1991; Widyastuti dan Aji, 2016). Hal ini secara jelas memberikan informasi bahwa pada postur cangkang langsing menunjukkan jenis kelamin jantan, sedangkan pada postur cangkang lebar menunjukkan jenis kelamin betina. 


\subsection{Nisbah Kelamin}

Salah satu parameter reproduksi untuk menentukan kemungkinan tersedianya induk jantan dan induk betina agar terjadi pemijahan adalah nisbah kelamin (Rochmady, 2011). Dalam kondisi normal, rasio jenis kelamin jantan dan betina antara satu (1) jantan berbanding satu (1) betina (Rochmady et al., 2012; Rochmady dan Rakhfid, 2014). Selain itu, nisbah kelamin menunjukkan adanya eksploitasi yang berlebihan terhadap salah satu jenis kelamin (Effendie, 1997; Rochmady et al., 2013), maupun indikasi adanya perubahan lingkungan (Susiana et al., 2013; 2017).

Pada perairan Madung, siput gonggong diperoleh sebanyak 1.124 individu yang terdiri atas dua spesies. Berdasarkan waktu pengumpulan sampel selama enam kali, jumlah siput gonggong jenis $S$. canarium jantan yang dikoleksi selama penelitian selalu lebih banyak daripada $S$. canarium betina (Tabel 3 ).
Nisbah kelamin $S$. canarium jenis kelamin jantan dan betina berbeda nyata, nilai chi-square hasil perhitungan sebesar 11,1578. Nilai chi-square tabel: $\chi^{2}(\alpha 0,05)$ sebesar 2,5706, $\chi^{2}$ hitung sebesar 11,1578. Dengan demikian, nilai $\chi^{2}$ hitung $>\chi^{2}$ tabel, maka dapat ditarik kesimpulan bahwa jumlah siput gonggong jantan dan siput gonggong betina berbeda nyata atau rasio $1 \neq 1$ pada setiap waktu pengumpulan (tolak $\mathrm{H} 0$, terima H1). Hal yang sama terjadi pada nisbah kelamin siput gonggong jenis Strombus sp. Jenis kelamin jantan dan betina Strombus sp. berbeda nyata, sebagaimana ditunjukkan dengan nilai chi-square sebesar 14.1579 (Tabel 4). Tetapi siput gonggong jenis Strombus sp. kelamin jantan sedikit lebih banyak dari kelamin betina. Pada masingmasing nilai chi-square hitung menunjukkan nilai yang lebih besar dibanding nilai chisquare tabel pada taraf kepercayaan 0,05. Hal ini berarti bahwa nisbah kelamin antara jantan dan betina menunjukkan perbandingan yang tidak sama $(1 \neq 1)$.

Tabel 3. Nisbah kelamin siput gonggong (S. canarium) jantan dan betina berdasarkan waktu pengumpulan sampel di perairan Madung, Kota Tanjungpinang, Indonesia.

\begin{tabular}{ccccc}
\hline Waktu Pengambilan & \multicolumn{2}{c}{ Jenis Kelamin } & \multicolumn{2}{c}{ Nisbah Kelamin } \\
\cline { 2 - 5 } Sampel & Jantan & Betina & Jantan & Betina \\
\hline I & 54 & 42 & 60 & 36 \\
II & 18 & 14 & 20 & 12 \\
III & 12 & 4 & 10 & 6 \\
IV & 78 & 64 & 89 & 53 \\
V & 13 & 3 & 10 & 6 \\
VI & 246 & 126 & 232 & 140 \\
Jumlah & 421 & 253 & 70 & 42 \\
\hline
\end{tabular}

Keterangan: $\chi^{2}$ hitung $=11,157, \chi^{2}$ tabel $=2,5706$.

Tabel 4. Nisbah kelamin siput gonggong (Strombus sp.) jantan dan betina berdasarkan waktu pengumpulan sampel di perairan Madung, Kota Tanjungpinang, Indonesia.

\begin{tabular}{ccccc}
\hline Waktu Pengumpulan & \multicolumn{2}{c}{ Jenis Kelamin } & \multicolumn{2}{c}{ Nisbah Kelamin } \\
\cline { 2 - 5 } Sampel & Jantan & Betina & Jantan & Betina \\
\hline I & 14 & 16 & 15 & 15 \\
II & 2 & 0 & 1 & 1 \\
III & 2 & 1 & 1 & 2 \\
\hline
\end{tabular}




\begin{tabular}{|c|c|c|c|c|}
\hline \multirow{2}{*}{$\begin{array}{c}\text { Waktu Pengumpulan } \\
\text { Sampel }\end{array}$} & \multicolumn{2}{|c|}{ Jenis Kelamin } & \multicolumn{2}{|c|}{ Nisbah Kelamin } \\
\hline & Jantan & Betina & Jantan & Betina \\
\hline IV & 60 & 72 & 66 & 66 \\
\hline V & 42 & 18 & 30 & 30 \\
\hline VI & 104 & 119 & 111 & 112 \\
\hline Total & 224 & 226 & 37 & 38 \\
\hline
\end{tabular}

Keterangan: $\chi^{2}$ hitung $=14,1579, \chi^{2}$ tabel $=2,5706$.

Nilai chi-square tabel: $\chi^{2}(\alpha 0,05)=$ 2,5706. Oleh karena $\chi^{2}$ hitung $>\chi^{2}$ tabel maka dapat ditarik kesimpulan bahwa jumlah siput gonggong jantan dan betina berbeda nyata pada setiap waktu pengumpulan (tolak $\mathrm{H}_{0}$, terima $\mathrm{H}_{1}$ ). Pemijahan siput gonggong di alam dan atau pada jenis kekerangan pada umumnya sangat ditentukan oleh kehadiran individu jantan dan betina (dioseus) pada lokasi yang sama untuk menunjang keberlanjutan suatu populasi di alam (Rochmady, 2011). Oleh karena kehadiran individu jantan dan betina cenderung akan memudahkan proses fertilisasi (Morton, 1983; Cob et al., 2008, 2010; Rochmady et al., 2012).

Secara umum, rasio kelamin siput gonggong jantan dan betina di perairan Madung tidak seimbang, yakni jumlah siput gonggong jenis kelamin jantan cenderung tidak sama dengan jumlah siput gonggong betina. Rasio kelamin siput gonggong yang tidak seimbang tersebut diduga kuat disebabkan oleh adanya tekanan eksploitasi yang berlebihan (Waris et al., 2014). Hal yang sama terjadi pada moluska jenis Anodontia edentula dimana rasio kelamin yang tidak seimbang akibat tingginya tingkat eksploitasi (Rochmady, 2011, 2012; Rochmady et al., 2013; Rochmady dan Rakhfid, 2014). Laporan berbagai penelitian menyebutkan bahwa perubahan rasio kelamin merupakan indikasi kuat adanya tekanan eksploitasi (Espinosa et al., 2009; Miah, 2015), sehingga organisme melakukan perubahan pola reproduksi baik berupa perubahan ukuran matang gonad maupun perubahan nisbah kelamin (Haug and Tjemsland, 1986; Gascoigne and Lipcius, 2004; Stelkens and Wedekind,
2010; Ruga and Huntley, 2017; Ramses et al., 2019). Hal yang sama dilaporkan Chim et al. (2009) tentang status siput gonggong di Singapura menunjukkan dengan jelas perubahan rasio kelamin akibat adanya tekanan eksploitasi.

Namun bagaimanapun, keadaan nisbah kelamin yang tidak seimbang dapat dipengaruhi kondisi lingkungan perairan (Cob et al., 2009c; Susiana et al., 2013) maupun faktor lain. Perubahan faktor-faktor fisika-kimia lingkungan habitat siput gonggong dapat mengakibatkan terjadinya perubahan rasio kelamin jantan dan betina (Utami, 2012). Bagaimanapun, perubahan rasio kelamin akibat perubahan kondisi lingkungan (fisika-kimia) maupun ketersediaan makanan terjadi dalam rentang waktu yang lama (Aranda et al., 1989; Kowalke, 2006). Selain itu, perbedaan rasio jenis kelamin siput gonggong diduga merupakan bagian dari strategi reproduksi (Munday et al., 2006). Morton (1983) menyebutkan bahwa pada keadaan normal (kondisi lingkungan optimum), rasio kelamin yang berbeda merupakan suatu strategi reproduksi pada keadaan lingkungan tertentu. Strategi reproduksi dengan rasio jantan dan betina tidak seimbang cenderung berada pada lingkungan lentik (perairan tergenang). Sedangkan individu jantan lebih banyak dibandingkan dengan jumlah individu betina merupakan salah satu strategi reproduksi untuk mengoptimalkan keberhasilan reproduksi pada lingkungan lotik (perairan mengalir). Namun demikian, rasio kelamin siput gonggong di perairan Madung terindikasi kuat telah terjadi eksploitasi berlebihan. 
Berdasarkan dimorfisme seksual siput gonggong terjadi pada awal proses ontogeny, siput gonggong jantan mencapai kematangan seksual pada ukuran yang lebih pendek dibandingkan siput betina (Cob et al., 2008). Terlepas dari itu semua, perlu dilakukan penelitian lebih lanjut untuk mengetahui faktor-faktor lingkungan kaitannya dengan keberadaan jenis kelamin jantan dan betina. Dengan harapan keberlanjutan populasi siput gonggong di alam bisa terjaga dengan baik.

\section{KESIMPULAN}

Identifikasi jenis kelamin siput gonggong secara morfologi dapat didasarkan pada bentuk cangkang yakni lebar dan langsing. Cangkang lebar menandakan jenis kelamin betina, cangkang langsing menandakan jenis kelamin jantan. Nisbah kelamin siput gonggong $S$. canarium maupun Strombus sp. adalah $1 \neq 1$ atau berbeda.

\section{UCAPAN TERIMA KASIH}

Riset $\begin{gathered}\text { Terima } \\ \text { dan }\end{gathered}$ Pengabdian Mepada Direktorat Kementerian Riset, Teknologi, dan Pendidikan Tinggi, Republik Indonesia atas pendanaan Hibah Penelitian Dosen Pemula tahun 2017, No: 101/UN53.01.1/KONTRAK $-\mathrm{LP} / \mathrm{I} / 2017$.

\section{DAFTAR PUSTAKA}

Adulyanukosol, K. and S. Poovachiranon. 2006. Dugong (Dugong dugon) and seagrass in Thailand: present status and future challenges. Proc. 3rd Int. Symp. SEASTAR and Asian Biologging Science, 2003: 41-50.

Amini, S. 1986. Studi pendahuluan gonggong (Strombus canarium) di perairan pantai Pulau Bintan-Riau. $J$. Penelitian Perikanan Laut, 36: $23-$ 29.
Aranda, D.A., A. Lucas, T. Brule, E. Salguero, and F. Rendon. 1989. Effects of temperature, algal food, feeding rate and density on the larval growth of the milk conch (Strombus costatus) in Mexico. Aquaculture, 76(3-4): 361-371. https://doi.org/10.1016/00448486(89)90087-2

Arifin, Z. 2011. Heavy metals concentrations in water, sediment and biota in Kelabat Bay, Bangka Island. J. Ilmu dan Teknologi Kelautan Tropis, 3(1): 104-114.

http://dx.doi.org/10.29244/jitkt.v3i1.7 839

Brito-Manzano, N. and D.A. Aranda, 2004. Development, growth and survival of the larvae of queen conch Strombus gigas under laboratory conditions. Aquaculture, 242(1-4): 479-487.

https://doi.org/10.1016/j.aquaculture. 2004.06.035

Carpenter, K. E. and V.H. Niem, (eds.). 1998. The Living Marine Resources of The Western Central Pacific. Volume 1. Seaweeds, corals, bivalves and gastropods. Vol. 1 cod. FAO Food and Agriculture Organization of The United Nations. Rome. 669 p.

Chim, C.K., M.L. Neo, and K.S. Loh, 2009. The status in Singapore of Strombus (Dolomena) Marginatus sowerbyorum Visser \& Man In't Veld, 2005 (Mollusca: Gastropoda: Strombidae). Nature in Singapore, 2:379-384.

Cob, Z.C., A. Arshad, J.S. Bujang, and M.A. Ghaffar, 2011. Description and evaluation of imposex in Strombus canarium Linnaeus, 1758 (Gastropoda, Strombidae): A potential bio-indicator of tributyltin pollution. Environmental Monitoring and Assessment, 178(1-4): 393-400. https://doi.org/10.1007/s10661-0101698-7 
Cob, Z.C., A. Arshad, J.S. Bujang, Y. Bakar, K.D. Simon, and A.G. Mazlan, 2012. Habitat preference and usage of Strombus canarium Linnaeus, 1758 (Gastropoda: Strombidae) in Malaysian seagrass beds. Italian J. of Zoology, 79(3): 459-467. https://doi.org/10.1080/11250003.201 2.670273

Cob, Z.C., A. Arshad, J.S. Bujang, and M.A. Ghaffar, 2008. Sexual maturity and sex determination in Strombus canarium Linnaeus, 1758 (Gastropoda: Strombidae). J. of Biological Sciences, 8(3): 616-621. https://doi.org/10.3923/jbs.2008.616. 621

Cob, Z.C., A. Arshad, J.S. Bujang, and M.A. Ghaffar, 2009a. Seasonal variation in growth and survival of Strombus canarium (Linnaeus, 1758) larvae. Pakistan J. of Biological Sciences, 12(9): 676-682. https://doi.org/10.3923/pjbs.2009.676 .682

Cob, Z.C., A. Arshad, J.S. Bujang, and M.A. Ghaffar, 2014. Spatial and temporal variations in Strombus canarium (gastropoda: Strombidae) abundance at Merambong Seagrass Bed, Malaysia. Sains Malaysiana, 43(4): 503-511.

Cob, Z.C., A. Arshad, J.S. Bujang, W.L.W. Muda, and M.A. Ghaffar, 2010. Metamorphosis induction of the dog conch Strombus canarium (gastropoda: Strombidae) using cues associated with conch nursery habitat. J. of Applied Sciences, 10(8): 628635.

https://doi.org/10.3923/jas.2010.628.6 35
Cob, Z.C., A. Arshad, M.A. Ghaffar, J.S. Bujang, W.L.W. Muda, and W.L. Wan, 2009b. Development and Growth of Larvae of the Dog Conch, Strombus canarium (Mollusca: Gastropoda), in the Laboratory. Zoological Studies, 48(1): 1-11.

Cob, Z.C.Z., A. Arshad, J.S.S. Bujang, and M.. A. Ghaffar, 2009c. Age, growth, mortality and population structure of Strombus canarium (Gastropoda: Strombidae): Variations in male and female sub-populations. J. of Applied Sciences, 9(18): 3287-3297.

https://doi.org/10.3923/jas.2009.3287. 3297.

Davis, M. 2005. Speces Profile: Queen Conch, Strombus gigas. Southern Regional Aquaculture Center. $111 \mathrm{p}$.

Davis, M., C. Hesse, and G.A. Hodgkins, 1987. Commercial hatchery produced queen conch, Strombus gigas, seed for the research and grow-out market. Gulf amd Caribbean Fisheries Institute, 38: 326-335.

Delgado, G.A., C.T. Bartels, R.A. Glazer, N.J. Brown-Peterson, and K.J. McCarthy, 2004. Translocation as a strategy to rehabilitate the queen conch (Strombus gigas) population in the Florida Keys. Fishery Bulletin, 102(2): 278-288.

Dody, S. 2011. Pola sebaran, kondisi habitat, dan pemanfaatan Siput Gonggong (Strombus turturella) di Kepulauan Bangka Belitung. Oseanologi dan Limnologi di Indonesia, 37(2): 339353.

Dody, S. 2012. Pemijahan dan perkembangan larva siput gonggong (Strombus turturella). J. Ilmu dan Teknologi Kelautan Tropis, 4(1): 107-113. http://doi.org/10.29244/jitkt.v4i1.781 1 
Effendie, M.I. 1997. Biologi Perikanan. Yayasan Pustaka Nusatama. Yogyakarta. $163 \mathrm{p}$.

Enriquez-Diaz, M.R., J.M. Volland, J.F. Chavez-Villegas, D. Aldana-Aranda, and O. Gros, 2014. Development of the planktotrophic veligers and plantigrades of Strombus pugilis (Gastropoda). J. of Molluscan Studies, 81(3): 335-344. https://doi.org/10.1093/mollus/eyv01 1

Espinosa, F., G.A. Rivera-Ingraham, D. Fa, and J.C. García-Gómez, 2009. Effect of Human Pressure on Population Size Structures of the Endangered Ferruginean Limpet: Toward Future Management Measures. J. of Coastal Research, 254: 857-863. https://doi.org/10.2112/08-1005.1.

Gascoigne, J. and R.N. Lipcius, 2004. Conserving populations at low abundance: Delayed functional maturity and Allee effects in reproductive behaviour of the queen conch Strombus gigas. Marine Ecology Progress Series, 284: 185194. https://doi.org/10.3354/meps284185

Hadi, F.M. 2016. Pemanfaatan Limbah Cangkang Gonggong Sebagai Adsorben Untuk Menyerap Logam Timbal $(\mathrm{Pb} 2+)$. [Skripsi]. Universitas Islam Indonesia. Yogyakarta. 48 p.

Haug, T. and J. Tjemsland, 1986. Changes in size- and age-distributions and age at sexual maturity in atlantic halibut, Hippoglossus hippoglossus, caught in North Norwegian waters. Fisheries Research, 4(2): 145-155. https://doi.org/10.1016/01657836(86)90039-1
Kowalke, T. 2006. Ecological implications of molluscan ontogenetic strategies Examples from aquatic ecosystems of the Cenozoic Iberian Peninsula. Lethaia, 39(3): 195-209. https://doi.org/10.1080/00241160600 731856

Miah, M.S. 2015. Climatic and anthropogenic factors changing spawning pattern and production zone of hilsa fishery in the bay of bengal. Vol. 7 cod. Weather and Climate Extremes. 109-115 pp.

Morton, B. 1983. The Molusca. Volume 6; Ecology Mangrove Bivalvia. Academic Press, Inc. Orlando, New York. 77-130 p.

Munday, P.L., P.M. Buston, and R.R. Warner, 2006. Diversity and flexibility of sex-change strategies in animals. Vol. 21 cod. Trends in Ecology and Evolution. 89-95 pp.

Muzahar, and A.A. Hakim, 2018. Spawning and development of dog conch Strombus sp. larvae in the laboratory. J. Ilmu dan Teknologi Kelautan Tropis, 10(1): 209-216. http://doi.org/10.29244/jitkt.v10i1.18 607

Ramses, F. Syamsi, and Notowinarto, 2019. Length-Weight Relationship, Growth Patterns and Sex Ratio of Dog Conch Strombus canarium Linnaeus, 1758 in the Waters of Kota Batam. OmniAkuatika, 15(1): 19-29. http://doi.org/10.20884/1.oa.2019.15. 1.611

Reed, S.E. 1991. Reproductive Anatomy and Biology of the Genus Strombus in the Caribbean: I. Males. In: Proceeding of the 44th Gulf and Caribbean Fisheries Institute. 427-438 pp. 
Robertson, R. 1959. Observations on the spawn and veligers of conchs (Strombus) in the Bahamas. J. of Molluscan Studies, 33(4): 164-171. https://doi.org/10.1093/oxfordjournals .mollus.a064817

Rochmady, 2011. Aspek Bioekologi Kerang Lumpur Anodontia edentula (Linnaeus, 1758) (BIVALVIA: LUCINIDAE) di Perairan Pesisir Kabupaten Muna. Hasanuddin University. 183 p. https://doi.org/10.2139/ssrn.3095399

Rochmady, R. 2012. Hubungan panjang bobot dan faktor kondisi kerang lumpur Anodontia edentula, Linnaeus 1758 di pulau Tobea Kecamatan Napabalano, Kabupaten Muna. Agrikan: J. Agribisnis dan Perikanan, 5(1): 1-8. https://doi.org/10.29239/j.agrikan.5.1. 1-8

Rochmady, R., S.B.A. Omar, dan L.S. Tandipayuk, 2012. Nisbah kelamin dan ukuran pertama matang gonad kerang lumpur Anodontia edentula, Linnaeus 1758 di pulau Tobea, Kecamatan Napabalano, Kabupaten Muna. Agrikan: J. Agribisnis dan Perikanan, 5(2): 25-32. https://doi.org/10.29239/j.agrikan.5.2. 25-32

Rochmady, R. S.B.A. Omar, dan L.S. Tandipayuk, 2013. Nisbah kelamin dan ukuran pertama matang gonad kerang lumpur (Anodontia edentula, Linnaeus 1758) di pesisir Lambiku, Kecamatan Napabalano Kabupaten Muna. Agrikan: J. Ilmiah Agribisnis dan Perikanan, 6(1): 1. https://doi.org/10.29239/j.agrikan.6.1. $1-9$
Rochmady, R. dan A. Rakhfid, 2014. Nisbah kelamin dan ukuran pertama matang gonad kerang lumpur (Anodontia edentula, Linnaeus 1758) di pesisir Pulau Buton, Kecamatan Wakorumba Kabupaten Muna. Agrikan: $J$. Agribisnis dan Perikanan, 7(1): 1-9. https://doi.org/10.29239/j.agrikan.7.1. $1-9$

Ruga, M.R. and J.W. Huntley, 2017. Conch fritters through time: human predation and population demographics of Strombus gigas, San Salvador Island, The Bahamas. PALAIOS,. 34: 383392. https://doi.org/10.1130/abs/2017am300900

Setyono, D.E.D. 2006. Karakteristik biologi dan produk kekerangan laut. Oseana, 31(1):1-7.

Siddik, J. 2011. Sebaran spasial dan potensi reproduksi populasi Siput Gonggong (Strombus turturella) di Teluk Klabat Bangka-Belitung. Institut Pertanian Bogor. Bogor. 79 hlm.

Stelkens, R.B. and C. Wedekind, 2010. Environmental sex reversal, Trojan sex genes, and sex ratio adjustment: Conditions and population consequences: INVITED REVIEW. Vol. 19 cod. Molecular Ecology. 627-646 pp.

Sugiyono, 2006. Statistika Untuk Penelitian. Penerbit Alfabeta. Bandung. 112 p.

Susiana, S., A. Niartiningsih, dan M.A. Amran. 2013. Kelimpahan dan kepadatan kima (Tridacnidae) di Kepulauan Spermonde. Agrikan: J. Agribisnis Perikanan, 6(5): 55-61. https://doi.org/10.29239/j.agrikan.6.0. 55-61 
Susiana, S., A. Niartiningsih, M.A. Amran, and R. Rochmady. 2017. Suitability of location for restocking clams Tridacnidae in the Spermonde Archipelago. J. Ilmu dan Teknologi Kelautan Tropis, 9(2): 475-490. http://dx.doi.org/10.29244/jitkt.v9i2.1 9284

Tiley, K., M.A. Freeman, I. Yen, and M.M. Dennis, 2019. Histology atlas and systematic approach to postmortem examination of the queen conch Lobatus gigas. J. of Shellfish Research, 38(1): 131. https://doi.org/10.2983/035.038.0113

Utami, D.K. 2012. Studi bioekologi habitat siput gonggong (Strombus turturella) di Desa Bakit Teluk Kelabat, Kabupaten Bangka Barat, Provinsi Kepulauan Bangka Belitung. 60 p.

Venkatesan, V. 2010. Marine ornamental molluscs. National Training Programme on Marine Ornamental
Fish Culture, 27-32 pp.

Viruly, L. 2011. The utilization of sea snail gonggong (Strombus canarium) from Bintan Island of Riau-Archipelago as natural seasoning. Institut Pertanian Bogor. Bogor. $111 \mathrm{p}$.

Waris, R.W.N., L.W. Zen, dan A. Zulfikar, 2014. Kajian Stok Siput Gonggong (Strombus canarium) Perairan Madong, Kota Tanjung Pinang, Provinsi Kepulauan Riau. J. Umrah, $: 1-15$

Widyastuti, A. and L.P. Aji, 2016. Beberapa aspek reproduksi siput Lambis lambis di Pesisir Perairan Yenusi, Biak. Oseanologi dan Limnologi di Indonesia, 1(3): 1-9. http://doi.org/10.14203/oldi.2016.v1i 3.74

Received : 22 July 2018

Reviewed : 27 February 2019

Accepted : 05 September 2019 
